UDC 821.161.2+111.1+179.9

DOI https://doi.org/10.32838/2663-6069/2020.2-3/28

Virych $N . V$.

South Ukrainian National Pedagogical University named after K. D. Ushynsky

\title{
THE PROBLEM OF EXISTENTIAL CHOICE IN THE PROSE OF V. NESTAIKO
}

As a verbal and symbolic projection of the archetype, the mythological image that reproduces the process of the "birth" of a new personality, according to ancient ideas, had to reproduce at the same time the process of the "death" of its previous embodiment.

Representing the initial stage of rebirth of an unrealized, self-unconscious being into an existing, thinking personality, this "abandonment" and placement into the other, hostile world, at the same time, is a symbolic embodiment of the conflict between two personal states in which the individual falls in the process of self-formation. This is the state of "blissful ignorance", "holy simplicity", which were typical of a person during his "plant" being (personification of this state in mythology is various evil, dark forces), and the state of comprehending the knowledge about the world and about himself and his place in the world. It is this knowledge that is the source that gives the archetypal child the strength to emerge victoriously from the most difficult situations and overcome stronger and more experienced enemies.

In the analyzed story of $V$. Nestaiko, the parallel, unreal world, in our opinion, also focuses on the character's inner inquiries, the problems to which the teenager also seeks to find answers.

As we can see, in different times and epochs the young character of the story on the ways of forming his personality faces mainly not specific problems of one or another epoch (social, political, etc.), although they are present in the story, but the same life problems. These are the problems of good and evil, mercy and cruelty, truth and deception, honor and dishonor, treachery and fidelity, ugliness and beauty - in all their multifaceted manifestations.

Leading his characters through different eras, the writer argues that the basis of personality is the choice of oneself, made on the basis of the choice of life values - the choice between good and evil. Because the confrontation between the characters of Nestaiko's story is not a problem of a certain epoch: it is an eternal problem and an eternal human choice. In the same way, the values on which this choice is based are not one-day values, but in all epochs relevant, eternal universal values, the attitude to which only makes a person become a Person.

Key words: artistic world, motive, selfishness, archetype, choice.

Problem statement. One of the most essential concepts of the philosophy of existentialism is the concept of choice. Despite the fact that in the process of being a person almost daily and almost every moment faces a certain situational choice, it is a general, fundamental choice through which all the most important concepts and principles of ethics and human coexistence are understood and implemented. It is a person's choice of oneself.

In this sense, S. Kierkegaard called the concept of choice the nerve of the worldview and human existence, because it is choice that makes a person become a Person, because, according to the Danish philosopher, a person is one who has chosen himself as a person. S. Kierkegaard states: "Either - or", otherwise, you are not a person, and therefore, in fact, a person is only one who has chosen himself as a person and since that moment has been forming himself as a person [5].
In view of the above said, the idea of J.-P. Sartre becomes clear, which in the Russian translation is manifested almost by a pun: "existence precedes essence". Since to be a person worthy of his purpose in life, it is not enough just to be born into the world and to exist like grass or dust on the way. A person is required to self-determine, to understand his own essence, to choose his own way of life; requires actions worthy of his human nature.

The most striking aphorism that reveals the meaning of the concepts of existence and essence are the words of Mavka from Lesia Ukrainka's "Forest Song", which had embodied the ideas of the philosophy of existence in her works half a century before the European existentialist philosophers did.

"But it is sad that you can't equate yourself with your life..." - says Mavka to Lukashe, noting the discrepancy between the deeply spiritual essence of the beloved and his earthly, spiritless existence, which actually 
damages, destroys his soul, because "personality is a wholeness that is self-determined $\langle\ldots\rangle$, creating the world where he lives, the world of his own existence" [11]. The twists and turns of Lukashe and Mavka's drama inevitably lead us to another existential problem: the problem of self-cognition and determination of one's place in existence, because what, if not a reproach for not understanding one's essence, can be found in the words of the forest girl:

Do not despise the blossom of your soul...<..>

That color is more charming than of a fern -

It creates treasures, not discovers them [6].

Thus, Ukrainian writers and thinkers of the late XIX - early XX century perfectly understood that the life choice of the individual is inextricably connected with the person's knowledge and awareness of himself, his life values, concepts and aspirations.

Analysis of recent research. It should be noted that the idea of the important role of self-knowledge in individual's spiritual formation was present in the philosophy of Ukrainian thinkers already back in the XVI-XVII centuries.

Thus, for example, scientists of the Ostroh Academy believed that the condition for the formation of man as a person is his penetration into the spiritual essence of sacred texts, and the prerequisite for "comprehension of the divine word" is self-knowledge [3].

In this respect, it is interesting to study the works of Vsevolod Nestaiko, a talented writer of the XXXXI centuries. In literary science, the writer's works were the subject of research by P. Kyrychenko, O. Papusha, N. Reznichenko, B. Saliuk, N. Sydorenko et al. Interest in studying the artist's works in their various aspects has not faded today. However, the existential direction of V. Nestaiko's prose deserves special attention, which explains the topicality of the given pilot study.

Setting the task. The aim of the article is to study the significance of the problem of choice in the existence of V. Nestaiko's characters.

The realization of this aim involves solving the following tasks:

- to reveal the mental prerequisites for the formation of a peculiar type of the characters' existence;

- to trace the influence of V. Nestaiko's artistic heritage on the self-formation of personality.

Main body. If we turn to the call "Know thyself!", which was claimed in the XVIII century by the brightest forerunner of European existentialism, H. Skovoroda, and his reflections on the need for self-absorption and cognition of one's soul as a necessary condition for choosing the right (and therefore happy) way of life, and take into account the repeat- edly expressed by ancient philosophers and Christian thinkers reasoning, it becomes clear that life choices made on the basis of awareness of their spiritual concepts and needs, their life values (i. e. on the basis of self-knowledge) is the main constituent, the foundation of person's self-formation and self-development, the basis of the phenomenon which K. Jung denoted with the meaningful word "selfishness".

Confirmation of the idea that person's self-awareness and self-formation (the acquisition of Selfishness) in all eras was relevant and was of great importance for both the individual and, apparently, for the society, can be found in the fact that this process is reflected in the collective subconscious of mankind (K. Jung), in one of a number of symbolic forms, which, according to the philosopher, accumulated ancient manifestations of the mental states of the human collective of a certain epoch [12]. Coming to the surface of our descendants' consciousness in periods of uncertainty, hopelessness archetypes seem to suggest a repeatedly tested pattern of behavior, because each most uncertain and most difficult situation for the individual has been experienced and overcome many times in the collective experience of generations stored in the subconsciousness.

These manifestations of the mental states stored in subconsciousness and connected with the formation of personality are reflected in the collective subconscious in the archetype of the "divine child".

As a verbal and symbolic projection of the archetype, the mythological image that reproduces the process of the birth of a new personality, according to ancient ideas, had to reproduce at the same time the process of the death of its previous embodiment. After all, the obligatory precondition for the rebirth of a being in another world or in another capacity is its death as a previous one, its rejection of the previous state. Archetypal rejection of the previous state, of the past, embodied in mythology in the motives of alienation of a mythical or fairy-tale child from the familiar world, his lonely trips to unknown worlds, various obstacles or threats that he always overcomes, despite his "abandonment" in threatening worlds and situations and despite his smallness, weakness and lack of experience.

Representing the initial stage of rebirth of an unrealized, self-unconscious being into an existing, thinking personality, this "abandonment" and placement into the other, hostile world, at the same time, is a symbolic embodiment of the conflict between two personal states in which the individual falls in the process of self-formation.

This is the state of "blissful ignorance", "holy simplicity", which were typical of a person during his 
"plant" being (personification of this state in mythology is various evil, dark forces), and the state of comprehending the knowledge about the world and about himself and his place in the world.

It is this knowledge that is the source that gives the archetypal child the strength to emerge victoriously from the most difficult situations and overcome stronger and more experienced enemies.

Thus, in the conflict between the knowledge about oneself, about the world that is born, and "sacred simplicity", ignorance of the pre-existent state overcomes knowledge. The "divine" archetypal child emerges victoriously in the struggle against the fiercest forces of darkness.

However, reproducing the archetypal symbolism, mythology consistently and stubbornly sends as some help to this child acquiring selfishness, either a hare, a wolf, pike, apple, river or any other natural product with which the child easily gets in contact, finds complete understanding, not because of his enrichment with experience or knowledge, but because of the preservation of naturalness: that childish simplicity, which the "divine" child does not lose during his journeys. It is the ability of the symbolic archetypal child to preserve the natural purity of the soul, a bright view of the world, despite the acquisition of knowledge and experience in the difficult circumstances of lonely journeys where Jung sees its "divinity".

The V. Nestaiko's story "Mystery of the old clown" is interesting in this regard, since the writer with extraordinary insight into the psychology of the character and the deep sense of the importance and complexity of the process of teenager's self-reflection and self-formation, modernizing the archetypal symbolism creates the appropriate for the spirit of his time fascinating story of spiritual maturity of a modern teenager child.

The reader finds the young character of V. Nestaiko's story in a boundary situation, which, according to K. Jaspers, motivates a person to cognize himself, to search for his own values, to develop his own view of the world. This is actually the stage when the individual begins to realize himself as a person, builds his own hierarchy of values, and therefore begins to understand what he wants from the world and what he wants to give to the world - that is, makes the most important choice in life: choosing himself as a person.

The boundary situation for Stepan Nalyvaiko is his moving from an ordinary, native village, where twelve years of his life passed among familiar landscapes, under the care of his beloved grandparents, in the company of friends known for many years.
The boundary situation, which always involves breaking a dynamic stereotype, in itself is always accompanied by negative emotions. For Nestaiko's character, it takes on a crisis character: as he met the new class, the boy failed to take the right tone and, instead of the approving laughter, which his old village friends used to give him in response to his jokes, they caused only ridicule and an insulting nickname Mukha (Fly).

This nickname and the constant buzzing behind his back, which accompanied boy's every step, further deepen the feeling of losing friends, increase the feeling of "abandonment" in an unfriendly and uncomfortable world, which due to its unfriendliness and incomprehensibility seems absurd to the boy.

Thus, in the story we see a fairly clear description of the situation of existential crisis, which forces the teenager not only to "tell himself about his relationship with the world", but also "to improve himself in internal controversy" [1, p. 3-19]. Despite the fact that new classmates (all these "Dmitrukha", "Spasokukotskyi" or "Monkin") are deeply unsympathetic to our character, the guy is still not inclined to blame only them for his "fiasco" in the new community. Recalling Hrytsko's grandfather's wise warning, "They don't wave their hands in the apiary", and analyzing his own behavior, the boy concludes: "If I hadn't stood out with my jokes, maybe they would have accepted me to their company on the very first day. <...> If I had behaved modestly, quietly, then it would have been possible to compete in wit with them... and gradually win their sympathy and affection..." [8, p. 15].

Together with longing for the usual life left in the village and old friends, along with the problems of entering an unfamiliar, unfriendly world, this dissatisfaction creates even more psychological discomfort for the teenager, provokes inner confusion and increases feelings of loneliness, abandonment.

The consolation for the boy in this crisis situation is "the restless wandering spirit of the ancestors, which motivates to go, go, go somewhere $<\ldots>$ just to see new horizons, measure new roads, meet new people..." [8, p. 18].

This "spirit of ancestors", the essence of which, as we see from the teenager's thoughts, lies in the indifference to the world, in the desire to know it, encourages the boy to seek solace in lonely journeys in a strange city, which, in the end, imperceptibly but persistently transformed this strange, unpleasant city in the native and beloved place: "I was just walking and walking and looking, and looking... and every day I loved Kyiv more and more" [8, p. 20]. 
In addition, there was one cherished place in the Ukrainian capital, where the "feet themselves brought" the boy. This place was the capital's circus, where Stiopa Nalyvaiko, still a second-grade student, visited during a trip to Kyiv and where, impressed by the sunny humor of a clown in a black and white check cap, he decided "once and for all": to be a clown. "A sunny clown who brings people joy and comfort, who makes them forget their troubles and failures, their twos in mathematics, who causes unrestrained, merry laughter on all continents, in all corners of the globe" [7, p. 21].

This cherished, sacred place for a boy, which since childhood has been associated with the expectation of a miracle, according to the laws of myth-making is to give the character a wonderful, extraordinary adventure - a miracle that should affect his physical or moral maturity.

V. Nestaiko, who, thanks to his sense of writing and knowledge of child psychology, strictly adheres to these "laws" and never deceives children's hopes, gives his character a wonderful encounter in this sacred for a teenager place.

Since this encounter, the amazing adventures of the boy have begun, which become in the further development of the plot the second, mysterious, inner plan of his life, and the work itself acquires elements of an adventure story. That is, since the moment when the strange clown Chuck in the circus handed Stiopa during the intermission such a desirable ice cream (which the boy, of course, could not buy himself...), a fantastic, adventurous stream has flown in a realistic story about the life of a rural teenage dreamer, taken from ordinary circumstances and transferred to unusual and not quite clear to him conditions of urban life, that is, with the appearing of the old clown in the work, two realities are intertwined: real and parallel to it - imaginary. This technique is also found in Nestaiko's fairy tales, where supposedly very real characters (Nusia from "Land of Moon Rabbits" or Vasia Hlechyk from "Land of Sunny Rabbits" and other real-life characters) come into the conditions of the unreal world and in these conditions they pass spiritual and moral hardening, testing on Selfishness.

In the analyzed story, the parallel, unreal world, in our opinion, also focuses on the character's inner inquiries, the problems to which the teenager also seeks to find answers, and the mysterious clown Chuck, as well as the mysterious "forest inspector" Yelisei Petrovych, symbolize this natural component of the archetypal image of the "divine child" that does not allow a person who acquires rational knowledge and experience and is in a state of reassessment of val- ues to break away from the sources of childish "divinity", and the "sacred simplicity" evokes harmony between emotionality and rationality of the person, between newly acquired and traditional values.

Each journey in time and space is like a step to the character's highest level of knowledge of the life and spiritual growth.

The first and second journeys to the past, which the clown Chuck invited Stiopa Nalyvaiko to, were in 1912 - a time when Chuck - a high school student was as old as Stiopa at the time of the story.

The third journey is a trip back to the terrible period of occupation of Kyiv by fascist invaders, during which the boy even had to visit the Gestapo dungeons to fulfill Chuck's request.

The fourth journey takes the reader together with the characters of the work back to the teenage years of the clown Chuck (the period between 1912 and 1917); the fifth journey leads to 1859, where Shevchenko lived in Pashkovska's house in Priorka, Kyiv, at that time.

The sixth and seventh journeys take the characters to the year 1648, a time when the war of liberation under the leadership of Bohdan Khmelnytsky was going on in Ukraine. The purpose of the next, eighth journey was to meet "one of the wisest and most interesting people who were born in our land and whom the Kyiv sky could see" [8, p. 196], - Hryhorii Savych Skovoroda. So, it was a journey to 1764, when Skovoroda came to Kyiv with the young Kovalynskyi. The ninth journey took place to year 1068, to Prince Rus, when a well-known rebellion broke out in Kyiv on the 15th day of September against Prince Iziaslav, who was afraid to arm the people even to repel the Pechenegs.

The tenth and last journey of Stiopa Nalyvaiko with the strange clown Chuck was not to the past, but, on the contrary, to the future, where the young reader saw the protagonist and his school friends in adulthood and realized that not all children's dreams come true; those children who even had certain defects in childhood can still grow up to be useful to society, to be happy people.

Each step of cognition and maturation, which the young character makes during a new journey, poses new, increasingly serious problems for the boy, requires an adequate response to them and new spiritual efforts to solve them.

Despite the fact that the author of the story takes his characters through different periods of history, the people that the young Nestaiko's character happens to meet and the situations in which he finds himself, and therefore the problems he has to solve, are 
not unique to a particular period of time, which a boy with his older friend miraculously get in.

Thus, when he was in Chuck's childhood, Stiopa had to confront with manifestations of human selfishness and permissiveness, which generates cruelty leading even to bloody crimes. The general's wife "Fairy"the wife of the trustee of the gymnasium where Chuck studies, could permanently deprive any high school student of the opportunity to study and thus crash his future only with her arrogant "Fough", but the stockbroker, with an extremely eloquent name: Peacock (the embodiment of pride and arrogance) Judovych (the embodiment of treachery and betrayal) Holozubinetskyi - the one with bare teeth (bare, sharpened teeth are a sign of savagery and predation), who pretends to be a "patron of art", to satisfy his pathological pleasure does not stop and tries even to kill the young acrobat Teresa, who was saved from a terrible death only by miraculous intervention in the situation of the "living woodland spirit" [8, p. 147] Yelisei Petrovych in the image of an ordinary old man, who miraculously finds himself in the gallery of the circus next to Storozhenko and Chuck, a high school student.

This bloody crime is committed by the henchmen of Holozubenetskyi: the untalented clown Red August, the scurvy circus administrator with the chicken-pox scars, the money-lover Anem (who, by the way, alternately blame each other, trying to avoid responsibility) and other pygmies endowed with at least a tiny bit of power and superiority over others, such as the circus doorman, who also helped to arrest the talented and honest, and therefore unacceptable to the mercenary circus administration clown Storozhenko.

As we can see, in different times and epochs the young character of the story on the ways of form- ing his personality faces mainly not specific problems of one or another epoch (social, political, etc.), although they are present in the story, but the same life problems. These are the problems of good and evil, mercy and cruelty, truth and deception, honor and dishonor, treachery and fidelity, ugliness and beauty - in all their multifaceted manifestations.

Leading his characters through different eras, the writer argues that the basis of personality is the choice of oneself, made on the basis of the choice of life values - the choice between good and evil. Because the confrontation between the characters of Nestaiko's story is not a problem of a certain epoch: it is an eternal problem and an eternal human choice! In the same way, the values on which this choice is based are not one-day values, but in all epochs relevant, eternal universal values, the attitude to which only makes a person become a Person.

Conclusions. Thus, the given pilot study proves the correspondence of the narrative to the archetypal symbolism: the character's abandonment in an unfamiliar world, hostility of the environment, loneliness, encountering in a sacred place miracle assisstants who help the character pass the path of self-formation and acquisition of Selfishness. Each new journey offered by the old clown to the protagonist gives him a new lesson of humanity and knowledge, makes the teenager intellectually and morally enriched.

Analysis of V. Nestaiko's novel "The Mystery of the Old Clown" convinces that it, like other works of the writer, involving children in a trusting and interesting conversation about good and evil, love and hate, nobility and meanness, beauty and ugliness, aims at shaping and improving the spiritual essence of the human soul.

\section{References:}

1. Анциферова Л. К психологии личности как развивающейся системы. Психология формирования и развития личности. Москва, 1989. С. 3-19.

2. Білодід Ю. Філософія: український світоглядний акцент : навчальний посібник. Київ : Кондор, 2006. 355 с.

3. Гуцол С. Психологічні особливості структурних складових неоміфологічного. Вісник Національного технічного університету Украӥни «Київський політехнічний інститут». Серія «Філософія. Психологія. Педагогіка». 2011. Вип. 1. С. 103-108.

4. Історія української філософії. Київ : Академвидав, 2008. 612 с.

5. Кьеркегор С. Или - или. Антология мировой философии : в 4 т. Москва : Мысль, 1971. Т. 3. С. 710 -711.

6. Мелетинский Е. Аналитическая психология и проблемы происхождения архетипических сюжетов. Вопросы философии. 1991. № 10. С. 41-47.

7. Нестайко В. Загадка старого клоуна : повість. Київ : Країна мрій, 2010. 272 с.

8. Салюк Б. Образ мегаполісу у творах для дітей Е. Кестнера та В. Нестайка. Актуальні проблеми слов'янської філологї. Серія «Лінгвістика і літературознавство» / гол. ред. В. Зарва. Бердянськ : БДПУ, 2010. Вип. ХХIII. Ч. IV. С. 82-189.

9. Сартр Ж.-П. Буття і ніщо: нарис феноменологічної онтології / пер. з франц. В. Лях, П. Таращук. Київ : Видавництво Соломії Павличко «Основи», 2001.854 с. 
10. Сидоренко Н. Жанрові модифікації і поетика української дитячої повісті 60-80-х років ХХ століття : дис. ... канд. філол. наук : 10.01.01. Херсон, 2010. 219 с.

11. Юнг К. Психологические типы. Москва : Университетская книга ; АСТ, 1996. 714 с.

\section{ВірИч Н. В. ПРОБЛЕМА ЕКЗИСТЕНЦІЙНОГО ВИБОРУ В ПРОЗІ В. НЕСТАЙКА}

У розвідиі проаналізовано творчість В. Нестайка в екзистенційному спрямуванні. Зосереджено увагу на майстерному моделюванні ситуацій і характерів. Як словесно-знакова проєкиія архетипу міфологічний образ, щз відтворює проиес «народження» нової особистості, згідно з прадавніми уявленнями, обов'язково повинен був відтворити й процес «загибелі» попереднього ї̈ втілення.

Як початкова стадія переродження неосмисленої, несамоусвідомленої істоти в екзистуючу, мислячу особистість, ия «закинутість» у чужий, ворожий світ є водночас символічним втіленням конфлікту між двома особистісними станами, у які потрапляє індивід у процесі самостановлення. Це стан того «блаженного невідання», «святої простоти», у якому перебувала людина у своєму «рослинному» бутті (уособленням иъьго стану в міфології є різноманітні злі, темні сили), і стан осягнення знань про світ, про себе та своє місие у світі. Саме ці знання є тим джерелом, яке надає архетипній дитині сили переможно виходити з найскрутніших ситуацій та долати сильніших і більш досвідчених ворогів.

В аналізованій повісті В. Нестайка паралельний, ірреальний світ, на нашу думку, фокусує також внутрішні запити героя, ті проблеми, відповіді на які прагне знайти підлітковий вік. Кожна сходинка пізнання та змужніння, на яку піднімає юного героя нова подорож, ставить перед ним нові, щораз серйозніші проблеми, вимагає адекватної реакиї̈ на них і нових духовних зусиль для їх розв'язання.

Як бачимо, у різні часи та епохи юний герой повісті на шляхах становлення своєї особистості стикається переважно не зі специфічними проблемами тієї чи іншої епохи (соціальними, політичними тощо), хоча й вони присутні в повісті, а з одними й тими ж життєвими проблемами. Це проблеми добра та зла, милосердя йжсорстокості, правди та облуди, честі й безчестя, продажності та вірності, потворності й краси, ще постають в усіх їхніх багатогранних виявах.

Ведучи своїх героїв різними епохами, письменник стверджує, щьо підтрунтям особистості є вибір себе, зроблений на основі виборужиттєвих иінностей-вибору між добром і злом. Адже протистояння між персонажами повісті В. Нестайка - ие не проблема певної епохи, це вічна проблема та вічний людський вибір. Так само иінності, на яких ией вибір базується, - ие не иінності-одноденки, а вічні, актуальні в усі епохи загальнолюдські цінності, ставлення до яких і робить людину Людиною.

Ключові слова: художній світ, мотив, самість, архетип, вибір. 